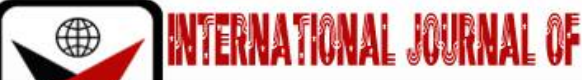

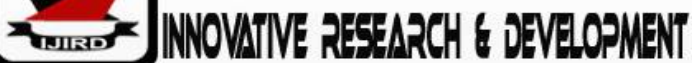

ISSN 2278-0211 (Online)

\section{Book Review: In Search of Respect}

\author{
Ningxin Li \\ Ph.D. Student, Department of Conflict Resolution, \\ Nova Southeastern University, USA
}

\begin{abstract}
:
In this paper, the author will analyze and critique the book: In Search of Respect. The author will explain how the author of the book successfully used the ethno graphic qualitative method to examine social and cultural influences on ethnic groups in East Harlem (El Barrio), New York (Bourgois, 2003). The author will illustrate how Bourgo is built close relations with participants including gang members and drug dealers and explain how Bourgois demonstrated social problems by observing participants' activities and interviewing local residents (Bourgois, 2003). In addition, the author will analyze how Bourgois investigated labor conflicts by living in the targeted area with Latino and African American immigrants. Moreover, the author of the book analyzed evidence for searching the dynamics of the social structure and power relations between different ethnic neighborhoods. The author will utilize Bourgois's research as an example to demonstrate how to conduct interviews in qualitative research.
\end{abstract}

Keywords: Economic depression, social segregation, cultural dynamics

\section{Introduction}

Bourgois had lived in a tenement apartment in El Barrio for three years (Bourgois, 2003). Bourgois' long stay in the neighborhood allowed him to get close to the residents and gain their trust. He found that poverty and racial discrimination might have caused social disorder in the neighborhood. Bourgois befriended several members of a drugselling gang, and he chose Caesar and Primo to be the participants in his qualitative research. Primo managed a crack store, called the 'Game Room' and Caesar is one of the lookouts for gang members. Bourgois had observed the living conditions of the participants and interviewed them. Bourgois revealed the street culture that contained violence and crime (Bourgois, 2003).

Bourgois had insights on social, political, and ethical dilemmas. Bourgois focused on the day-to-day lives of the Latino and African American immigrants in El Barrio (Bourgois, 2003). Bourgois found profound social problems in the neighborhood by interviewing people of different ethnicities and cultural backgrounds. He noticed that most of these Latino and African American immigrants did not receive equal treatment as the white Americans. He emphasized that a society should not ignore the needs of minority groups (Bourgois, 2003).

Bourgois utilized qualitative ethnography approaches to understand different cultures and the social structure within the targeted community (Willis, 2007). In Search of Respect indicated that both documented and undocumented immigrants had increased in East Harlem over the last decade (Bourgois, 2003). It was hard for the undocumented immigrants to find jobs and survive because many of them had alow income, which might prevent them from supporting their families. These immigrants were identified as illegal workers and a lot of them had been deported (Bourgois, 2003).

Bourgois investigated the problems that the so illegal immigrants had encountered and explained the difficulties they had experienced (Bourgois, 2003).He interviewed several women and young people among the Latino and African American immigrant population who were related to illegal drug dealing. Bourgois faced the challenge of how to get close to these people in order to interview them because they might be dangerous since they might be drug dealers. After interviewing, Bourgois found that emotional abuse had a significant impact on these immigrants and drug dealers. Mental or physical abuse during their childhood had affected their violent behaviors (Bourgois, 2003). Bourgois indicated that according to the standard of psychological theories of early childhood socialization, some immigrants in El Barrio might be dismissed as antisocial sociopaths. Their early childhood socialization experiences might influence their behaviors since they showed emotional scars during the interviews (Bourgois, 2003).

One participant, an elderly woman, was often worried about her family because her children could not find jobs (Bourgois, 2003). Her 26-year-old son was lazy, never had a long-term relationship, and was frequently drunk. Bourgois investigated how unemployment and poverty could limit individual's opportunity to find a job and increase the likelihood of criminal behaviors, such as drug dealing (Bourgois, 2003).

The qualitative research was well-organized in the book In Search of Respect. This method was participatory and helped in producing objective explanations for a phenomenon (Elder \& Miller, 1995). Bourgois successfully used the ethnographic research method, discussed the cultural dynamics, as well as exhibited the barriers to the local residents when they tried to obtain legal jobs (Kirner \& Mills, 2020). 
Moreover, Bourgois visited Puerto Rico and investigated how economic dislocation and personal bias had led to social conflicts (Bourgois, 2003). Bourgois analyzed cultural clashes between the residents of different backgrounds: the foreign-born, the native-born children of immigrants, and the children of long-time residents. The immigrants who were originally from other countries in Puerto Rico had different educational levels and occupational backgrounds(Bourgois, 2003). According to Bourgois's observation, the African Americans were poorer than the white Americans. In addition, Bourgois demonstrated how these people were isolated from mainstream society and recorded different conversations of participants. The participants had explained how they were affected by social marginalization and racial discrimination (Bourgois, 2003).

Bourgois's research indicated that prejudice and misunderstanding towards other people with different cultural backgrounds would cause social segregation (Bourgois, 2003). One of the participants described her experiences to Bourgois; she said that she did not have a refrigerator and would eat bacalao, which could keep fresh for a while, and ate meat from a can (Bourgois, 2003). Shes aid that her neighbors would look down on people who were poor, as well as spoke rudely by saying, 'they are not like us. We are Americans... What do they eat? Beans!' (Bourgois, 2003). The women in that area had to make extra money by baby-sitting or housekeeping when the men in their family could not support them financially (Bourgois, 2003).

Bourgois emphasized how economic depression could lead to long-term poverty and explained how poverty led to increasing criminal activities (Bourgois, 2003). He indicated that 'criminal traditions' initiated 'a vicious cycle' among young people(Bourgois, 2003). These people could convert a community to a drug supermarket as well as generate violence in a community. In addition, another participant told Bourgois about 'a deadly shotgun shooting outside my apartment window of a drug dealing woman; A bombing and a machine-gunning of a numbers joint by rival factions of the local Mafia' (Bourgois, 2003). Bourgois clearly and vividly presented the dialogues of this participant by actively communicating (Bourgois, 2003).

In order to collect data under a natural environment, Bourgois conquered many difficulties during the research (Bourgois, 2003). He spent hundreds of nights in the crack houses in order to observe participants' behaviors and collect data. Bourgois asked about the participants' experiences, analyzed their dialogues, found the root problems in the communities, and understood the needs and interests of these people (Bourgois, 2003).

\section{Conclusion}

In Search of Respect outlined different ethnic communities and presented different street cultures that were created by immigrants. This book explained how poverty and racism affected people's choices and their well-being (Bourgois, 2003). Bourgois comprehensively interpreted social conflicts in terms of psychology, ethnography, humanistic sociology, economics, and culture. He demonstrated the causes of social problems and racial segregation and provided meaningful dialogues between the participants and himself (Bourgois, 2003).The goal of Bourgois conducting the research included urging the local authorities to take active methods to prevent criminal activities, as well as giving ideas about teaching and training for the children in the community (Bourgois, 2003). Bourgois also encouraged individuals to seek jobs so that they would be able to build healthy and pleasant families. Bourgois successfully described how he overcame the challenges during the interviewing process and rationally conducted data analysis. Bourgois's book presented objective and reliable evidence for further researching social issues inEl Barrio (Bourgois, 2003).

\section{References}

i. Bourgois, P. (2003). In Search of Respect. NY: Cambridge University Press.

ii. Elder N., \& Miller, W., L. (1995). Reading and Evaluating Qualitative Research Studies. J Fam Pract. Vol. 41(3), pp. 279-285.

iii. Kirner, K., \& Mills, L., J. (2020). Doing Ethnographic Research: Activities and Exercises. CA: SAGE Publications.

iv. Mauthner, M. \& Birch, M. (2012). Ethics in Qualitative Research. CA: Sage Publications.

v. Willis, Jerry W. (2007). Foundations of Qualitative Research. CA: Sage Publications. 